\title{
Exploring the Perception of Students using Student-Centered Learning Approach in a Malaysian Public University
}

\author{
Abderrahim Benlahcene ${ }^{1}$, Sana Anwar Lashari ${ }^{1}$, Tahira Anwar Lashari ${ }^{2}$, Muhammad Waleed Shehzad ${ }^{3} \&$ Wu Deli ${ }^{1,4}$ \\ ${ }^{1}$ School of Education and Modern Languages, Universiti Utara Malaysia (UUM), Malaysia \\ ${ }^{2}$ School of Electrical Engineering and Computer Science, National University of Sciences \& Technology (NUST), \\ Pakistan \\ ${ }^{3}$ Department of English, Foundation University Islamabad (FUI), Islamabad, Pakistan \\ ${ }^{4}$ School of Education, Beibu Gulf University, China \\ Correspondence: Sana Anwar Lashari, School of Education and Modern Languages, Universiti Utara Malaysia \\ (UUM), Malaysia
}

Received: October 30, 2019

Accepted: December 28, 2019

Online Published: January 7, 2020

doi:10.5430/ijhe.v9n1p204

URL: https://doi.org/10.5430/ijhe.v9n1p204

\begin{abstract}
This study investigated students' perception towards language courses using student-centered learning approach at University Utara Malaysia (UUM). Students' perception was measured through a model termed as environmental, cognitive, affective, and metacognitive mediation (ECAM) which is a common teaching and learning technique used in classroom activities. To assess the implementation of ECAM; qualitative analysis was conducted based on observations of students' activities in two language courses. The findings of the study indicated that the students employed the techniques of ECAM model. However, cognitive mediation learning technique was extensively used by the students. Moreover, audio-taped interviews were also conducted with four voluntary undergraduate students. The findings from the interviews' interpretation revealed that students also explicit positive viewpoints about student-centered learning approach.
\end{abstract}

Keywords: student-centered learning, environmental, cognitive, affective, and metacognitive mediation, qualitative

\section{Introduction}

Literature since the year of 1990s has focused on the student-centered learning approach (Land \& Hannafin, 2000). Constructivist viewpoint posits that learning is an active process of construction and acquisition of knowledge. Based on the constructivist viewpoint, the learning environment is a place where students get the appropriate knowledge resources and skills with appropriate guidance and support from the instructors (Khan, 1997). Therefore, in this manner, constructivist view requires consideration of both students' and teachers' roles in learning activities whereby the lecturer plays a facilitator's role and the students play a central role. The difference in beliefs regarding teaching and learning can have an effect on students' perceptions about student-centered learning approach and impede students' participation in learning activities and learning contexts. There has been little focus paid to students' beliefs, perceptions, and challenges in learning contexts (Lee, 2009).

Consequently, the purpose of current research is to observe the mediating role of students in classroom activities. Mediational approach to learning are explained through two theories which are Vygotskian socio-cultural theory (SCT) (Vygotsky, 1978) and Feuerstein's theory of Mediated Learning Experience (MLE) (Feuerstein \& Feuerstein, 1991). The main ideas of both the theories lies in exploring the socio-cultural that plays a significant role in shaping the learners development such as from a novice to taking ownership of their learning and become an expert (Abdul Rahim, Hood, \& Coyle, 2009). According to Abdul Rahim (2007), the central claim of this model is based on four types of mediation needed in collaboration and interaction to provide maximum opportunity for both teachers and students to develop the learning process. This model of mediation was used as the student-centered learning approach is based on the idea that the learners are ate the center of the learning process and the teachers are facilitators of this process instead of being dominant agents in the classroom (Hannafin \& Land, 1997; Lee, 2009). Moreover, student-centered learning approach includes several techniques of mediation that could be observed via the lenses of ECAM model of mediation to gain more precise pictures regarding students' behaviors during their classroom's activities. 


\section{Theoretical Framework}

Vygotsky's socio-cultural theory claims that there is a relationship among learning, thinking and knowing (Wang, 2007). The current work builds on socio-cultural theory as a theoretical perspective. This theory is useful for exploring the application of student-centered learning approaches. A primary principle of Vygotskian psychology is that the individual's mental functioning is naturally located in social interaction, cultural and historical contexts (Bonk \& Cunningham.1998). Therefore, to understand human thinking and learning, there is a need to examine the context in which thinking and learning happens with respect to ECAM model of mediation (Abdul Rahim, 2007). It is important to study the mediational effect based on the socio-cultural theory perspective which claims that understanding the mediational effect is crucial to characterize the achievement of learning activities. In the learning context, mediation defined as the process in which learners develop their mental processes or habits of mind during collaboratively constructed dialogic activity to achieve higher mental functions so that they will be able to later transform their learning (Kozulin, 2002).

\section{Literature Review}

\subsection{Student-Centered Learning Approach}

The main philosophy of student-centered learning approach is to encourage students' engagement and active learning which enhances students' independent thinking, knowledge and skills, which in turn improves critical thinking (Brooks \& Brooks, 1993; Eggen \& Kauchak, 2001; Holt \& Kysilka, 2006; Kornell \& Bjork, 2007). Moreover, students' role in student-centered learning approach is significantly different from their role in teacher-centered learning approach (Hannafin \& Land, 1997; Lee, 2009). Therefore, it is important to identify perceptions of students about teaching and learning processes and their perceptions regarding student-centered learning contexts.

Student-centered learning includes mediation tools such as collaborative learning, cooperative learning, problem-based learning, small group learning, and project-based learning. Previous studies have argued that the student-centered learning approach has many advantages more than traditional teaching curriculum (Asoodeh et al., 2012; Baeten et al., 2010; Jones \& Thomas, 2005; Thanh, 2010; Wijnia et al., 2011). However, there is only one significant approach that takes environment, cognitive, affective and metacognitive processes into account collaboratively known as ECAM model of mediation. This model was introduced by Abdul Rahim in 2007.

\subsection{ECAM Model of Mediation}

Abdul Rahim (2007) proposes that a human capacity to learn can be achieved by providing a model for mediation. The model of mediation is a combination of a supportive learning environment that challenges the learners, yet facilitates the learning process via four elements namely environmental, cognitive, affective and metacognitive (ECAM). The environmental mediation establishes an environment and context that challenges and promotes students' learning. The cognitive mediation supports and enhances the learning process through challenging learners' thinking. The affective mediation is related to emotion, warmth and affective involvement of the mediator. It tends to enhance learners' motivation in the classroom, raising self-esteem and thus promoting moral values. The metacognitive mediation is a learning process which promotes self and other regulation such as during the metacognitive mediation; the learners are aware of their cognition and developing competence; therefore, adequate learning strategies and planned thinking are used.

Since the mediational tools enable the teachers to change and sustain new pedagogical approaches within the classroom activities (Abdul Rahim, 2007), therefore, it is argued that the ECAM model of mediation provides opportunities for instructors and students to expand their capacity to learn and develop their personalities as individuals capable of learning and becoming experts.

\subsection{Asian Countries Perspective}

Asian countries have recently tried to change the traditional approach which is based on teacher-directed learning to a more contemporary approach which includes student-centered learning activities, such as problem-based learning, collaborative learning, inquiry-based learning, cooperative learning, small group learning, peer led team learning, and project-based learning. This is because there is a growing evidence which indicates that these learning activities can help learners effectively in developing the knowledge and skills that Asian students often lack as mentioned in the previous studies (Cooper, MacGregor, Smith, \& Robinson, 2000; Handelsman et al., 2004; Pham \& Renshaw, 2013). In attempting to achieve this change, every year Asian governments spend a great amount of money in instructors' development such as conducting workshops and conferences to train instructors on the methods of student-centered approach. They have also funded and sent thousands of teachers and administrators overseas to learn about new approach (Pham \& Renshaw, 2013). Unfortunately, even though the continuous efforts have been 
made, the image of Asian classrooms is still perceived as a passive, non-participative and instructor-dominated learning environment (Adamson, Kwan \& Chan, 2000; Jones, 2007; Pham \& Renshaw, 2013). Nevertheless, Nguyen (2008) highlighted that the resistance to change occurred mainly because Asian teachers often found new approach difficult to accept.

In Vietnamese Higher Education, Thanh (2010) reported that a student-centered learning is seen as an ideal for local reforms in the field of education because it provides learners the skills requested by the labor market such as independence, creativeness, effectiveness and the spirit of cooperation. However, the implementation of new approach requires great changes in the structure of the traditional teaching contexts in terms of teaching and learning methods as well as physical characteristics. According to Thanh (2010), the variety of local infrastructure settings and cultural barriers can hinder the implementation of students-centered learning approach. Pham (2011) examined the present teaching and learning reforms at several Asian higher education institutions. The findings indicated that Western-developed practices such as group work have been widely applied in classrooms of Asian higher education institutions. However, a majority of the instructors and students did not consider the practices as being better than their traditional activities based on increasing students' academic performance, developing new ideas and skills.

There are five areas that needed to be changed in order to achieve learner-centered learning: the choice of content, the instructor's role, responsibility for learning, the process of assessment, and the power relationship between instructors and students. It is necessary for students to take ownership of their own learning, some contribution to the design content of curriculum (Humaid, Lashari. Saoula, Lashari, Benlahcene, \& Lubana, 2019) and the responsibility for some levels for education (Ahmed, 2013). Similarly, Bain (2011) determined several traits of teachers who employ learner-centered instruction approaches. Among these characteristics are that teachers touch the lives of their learners, they place a strong emphasis on student learning and outcomes by conducting different forms of assessment, and the effect on the professional goals of students (Benlahcene, Lashari \& Lashari, 2017). Liu, Xiao and Liu (2006) highlighted that while learner-centered language teaching has been advocated in higher education in recent decades, teacher-centered styles may still be prevailing in actual activities. Findings of their research show that most instructors still use traditional, teacher-centered styles in university settings despite the call for a paradigm shift to learner-centered learning context in classrooms. Brown (2008) reported that student-centered learning context provides students' ownership over their learning process and helps them make decisions and value judgments about the importance the content of curriculum and the ways of teaching to their own lives and their interests. In addition, in student-centered learning approach, students play essential roles in the development and designing of their own educational curriculums. The instructors play the role of a mediator or guide who helps learners to get their goals (Wolk, 2010). Saulnier, Landry, and Wagner (2008) concluded in their study that learner-centered context contributed to the construction of educational practices and provided for more student learning and student assessment.

Walsh and Vandiver (2007) found that learners performed better academically because they had an opinion in what they learned, and the instructor only worked as mediators in order to enable the learners to learn effectively. Wohlfarth et al. (2008) tested the idea that the learner-centered approach departs from teacher-centered by focusing on learners and learning process more than instructors and teaching. Graduate students in student-centered classrooms were examined about perceptions of their experiences in relation to the main dimensions of the learner-centered learning approach and indicated that the approach makes them feel respected as learners, developed their critical thinking skills, and enhanced their self-directed ability. Overall, graduate students in student-centered classrooms agreed that their classroom experiences were indeed learner-centered. Several researchers highlighted the advantages of student-centered learning approach (e.g., Asoodeh et al., 2012; Baeten et al., 2010; Jones \& Thomas, 2005; Thanh, 2010; Wijnia et al., 2011). The aforementioned studies argued that student-centered learning approach has many advantages as compared to traditional teaching approach including boosting motivation among students , increasing peer communication, effectively involving the learners in learning process, developing self-confidence among students, establishing strong relationships between students and instructors, strengthening the creativity among students, enhancing students' responsibility and autonomy, providing opportunities for students to develop general skills, communication skills, effective decision making and self-regulation.

From the previous research, we can expect that students would demonstrate implementation of ECAM's model of mediation during their activities in the classroom. Student-centered learning approach would provide a lot of advantages to the learning and teaching process, while the lecturers would play a role of a mediator and facilitator in an educational process to encourage students to develop their skills to become more active and autonomous in learning. However, the function of the curriculum under the student-centered learning context is not only to provide strong background of discipline, but also to improve skills and self-awareness among the students to become 
self-regulated learners. In order to achieve this goal, a closer look on how the students behave during English lessons, with particular attention to types of ECAM model of mediation, their perception about new approach is necessary.

\section{Aim of the Current Study}

The current study examines the perceptions of students about implementation of student-centered learning approach and the importance of learning through mediation in enhancing students' capacity to learn with respect to a model of mediation that considers the environmental, cognitive, affective and metacognitive aspects of learning and by promoting the idea of collaboration in higher education. Toward this end, we have two research questions- (1) how the students learn through environmental, cognitive, affective and metacognitive mediation throughout their learning session? And (2) how the students perceive student-centered leaning approach?

\section{Method}

\subsection{Participants}

The current study provides an analysis of two groups which participated in Japanese and English lessons. The researchers observed their activities during the two lessons (approximately 90 minutes for each group) by taking field notes. Interviews' participants included 4 voluntary students ( 3 females, 1 male) enrolled in the language courses at the UUM. The respondents of this study were selected purposefully to maximize variation in terms of cognitive beliefs, majors, ages, and prior experiences in the language courses. The respondents were two students from English classroom (Mimi and Lili) and other two students from Japanese classroom (Tina and Lee).

For observations, we selected the groups in which teacher's approval to take notes during their lessons, two teachers voluntary to conduct the observation in their classrooms. Only one teacher allowed us to make video in her lesson (English classroom). Importantly, we did not select groups for analysis based on any characteristics related to student-centered learning; the selection of groups occurred prior to analysis.

\subsection{Materials}

Classroom Observations. The purpose of classroom observation includes the opportunity to record information as it occurs in a context, =study real behavior, and examine individuals who have difficulty verbalizing their ideas (Creswell, 2012). In this study, one of the materials included field notes to observe the activities of students in language courses through environmental, cognitive, affective, and metacognitive (ECAM) mediation inside classrooms. Field notes was used in Japanese lesson only. In English lesson, the instructor allowed us to conduct video observation during the activities in classroom.

Semi-structured Interviews. The implementation of interviews provide useful information when you cannot directly observe practices of participants, and permit participants to describe detailed personal information (Creswell, 2012). The semi-structured interviews were conducted after obtaining approval of voluntary students who are ready to share their perceptions about student-centered learning approach. I was able to collect comparable data among students. The interviews in this study were conducted with four students (two students from each class) which ranged from 20 to 45 minutes and tape-recorded by handphone (see Appendix for interview materials). The interviews were semi-structured to make sure that all relevant topics were covered.

\subsection{Study Design}

In order to achieve the research objectives of the current study, qualitative research approach was employed involving two phases. The first phase was the observation phase, which involved observing the existing students' practices. The second phase was the interviews phase, which involved the semi-structured interviews with students about student-centered learning approach. Corbin and Strauss (2014) pointed out that qualitative methods are appropriate for those studies which are intended to understand the experiences of people, explore areas to gain novel understandings, and get detailed information about phenomenon that is difficult to access through quantitative research method. A qualitative approach was selected because this study was designed to explore the rich and detailed learning experiences of undergraduate students in the language courses through ECAM model of mediation and to better understand their perceptions of a student-centered learning approach.

\section{Data Collection}

In order to ensure validity of a study, triangulation is done by employing more than one data collection methods so that they validate each other (Denzin, 1989, 1970). In the current study, data was gathered by employing two distinct methods, i.e., observation and interviews. 
It is worth mentioning that observations were conducted prior to interviews. The main rationale of conducting observations was to acquire direct knowledge of the practices that happen in real settings (Merriam, 2009). In the current study, two observation sessions were conducted by two teachers. One of them was Japanese language teacher (three years of teaching experience) and another was English teacher (five years of teaching experience) in undergraduate programs at UUM in Malaysia. The first observation session was conducted during lesson of Japanese language, while the second session was conducted during lesson of English language. Both the observation sessions involved 18 students. The observer took detailed notes of the students' activities related to the types of ECAM model of mediation.

After finishing the observations phase, we moved to conduct the interviews with four students (two students from each class) who approved to share their perceptions about student-centered learning approach (see Appendix for interview materials). More particularly, semi-structured interviews were conducted. In this type of interviews, generally, major questions or certain key topics are already selected before the start of interview, yet the possibility is there to ask questions other than the fixed ones depending upon the responses of the interviewee (Kajornboon, 2005). The interviews were ranged from 20 to 45 minutes and tape-recorded by hand-phone to transcribe the data gathered from participants.

\section{Data Analysis}

To analyze the data, the interviews and classroom activities' observation notes were transcribed in full into written form in order to conduct a thematic analysis. Coding is a process by which researchers define what is happening in the data and name actions and events. In the current study, actions and information of students are compared with other incidents, and similar incidents are grouped into categories. To do this, in the first observation (i.e., Japenese lesson), we used the field notes. In this particular step of analysis, we considered the techniques which were employed by the students in their activities and made notes about the type of ECAM model of mediation as a code in which the students used its techniques during one activity (see Table 1 for a list of codes and techniques). For second observation (i.e., English lesson), we used video recordings. The researcher watched video recordings of the listening training and noted on each behavior from the students with respect to the techniques in the types of ECAM model of mediation to start the coding process on the transcripts. As the activities occurred after the listening period (parts of the listening training), so the transcripts of the video recordings focused on the time between each parts of listening process.

To analyze the perceptions of the students about student-centered learning approach, we asked them to share their beliefs about this new approach. The interviews with four undergraduate students (two from each lesson) for this study were audio-taped. Additionally, transcription is the process of converting audio tape recordings or field notes into text data (Creswell, 2012). In this way, we transcribed the data into written form to conduct the analysis. After reading through the data several times, we generated preliminary list of analytic themes, noted down initial ideas related to the perceptions of students about SCL, returned to the data in several semi-structured to coding sessions to explore the interesting features and collated the data relevant to each code (Braun and Clarke, 2013). Initially, we paid attention to the shared themes across the students, paying careful attention to the nuanced answers told by each student. At a later stage of our analysis, we examined the ways in which each student perceives the implementation of SCL.

Finally, after completing the prior steps for each of the four students, we proceed to final step. In the final phase of analysis, we compared the four students on each primary code to identify meaningful differences and similarities between the perceptions of the students. We gained insight into the power of inviting the teachers to conduct SCL in their lessons in aspects of main codes such as environment, interaction, engagement, content, assessment and instructional strategies. 
Table 1. Description of the codes and its techniques

\begin{tabular}{|c|c|}
\hline Codes & Techniques \\
\hline \multirow[t]{3}{*}{ Environmental } & Task design: for collaboration, for various levels; Challenge; task regulation. \\
\hline & Materials and equipment -learning materials, use of technology, visual aids. \\
\hline & The learning environment: physical setting of the classroom, setting for discussion. \\
\hline \multirow[t]{2}{*}{ Cognitive } & Resources and rules: \\
\hline & $\begin{array}{l}\text { Contingent responsively, questioning, reciprocal teaching, modeling, demonstration, } \\
\text { hints, prompts, providing help, alerting another's attention to a concept or skill by } \\
\text { providing and offering explanations, eliciting explanation, providing suggestion, help } \\
\text { seeking, referencing, meaning, Intentionality, analytical thinking }\end{array}$ \\
\hline \multirow[t]{2}{*}{ Affective } & $\begin{array}{l}\text { Global values: building confidence, gaining trust, use of humor, caring, showing } \\
\text { warmth, encourage to motivate one self, value. }\end{array}$ \\
\hline & $\begin{array}{l}\text { Use of feedback: emotive feedback, accepting praise, emotional peer support, } \\
\text { encourage creativity and elements of fun. }\end{array}$ \\
\hline Metacognitive & $\begin{array}{c}\text { Self-planning, group planning, checking self and others, monitoring self and others, } \\
\text { evaluating self and others, change. }\end{array}$ \\
\hline
\end{tabular}

\section{Result}

In this section, we present the qualitative results that address the two research questions. These results focus on (a) students learning through mediational tools in classroom activities and (b) perceptions of students about student-centered learning approach in language courses at UUM.

Question 1: How the students learn through environmental, cognitive, affective and metacognitive mediation inside a classroom in UUM?

This section presents results from the observations during two lessons to explore how students learn through mediational tools. Thus, our goal was to highlight the ways that students learned by using the mediation techniques of environmental, cognitive, affective, and metacognitive tools and to characterize the quality of these processes for supporting learners' self-regulation.

Environmental mediation. We observed instances of environmental mediation throughout students' work on the tasks. As expected, almost all of the students set in setting which enhance collaborative discussion during the activities. In the first stage of observation (i.e., Japanese lesson), the students sometimes used visual aids in their tasks such as power point. Moreover, the usage of technology was observed during English lesson because the lecturer used the materials of listening to train her students on listening skills. The usage of tools provided environmental mediation to motivate students to engage in the tasks. The usage of materials and equipment was evident from field notes and transcripts. The instructor had provided environment that mediated the learning process of students to get confidence and motivation during their activities.

Cognitive mediation. The students used cognitive mediation technique more than other mediational tools during Japanese language lesson. The students interacted with each other in activities such as pair discussion. In the first stage of observation, the students explained the speech to each other and also translated some words (demonstration). Additionally, the students used the questioning technique with each other and their instructor. Moreover, the students sought help from each other, when they had misunderstanding. For example, in one case, the teacher asked "how", and then the student explained the grammar to the teacher and his classmates (eliciting explanation). In a nutshell, during the Japanese lesson, the students employed numerous cognitive mediation techniques including questioning, eliciting explanation, demonstration, providing help to each other, use intentionality to learn, reciprocal teaching, accepting prompts from instructor and their mates. During English listening lesson, the students frequently used eliciting technique for explanation of their answers. For example, when students answered, teacher asked them the reason of choosing that specific answer. Consequently, the students read and explained their answers. These strategies can challenge and promote the student's thinking by supporting the learning of the concept.

Affective mediation. This type of mediation was used less frequently based on observations of two lessons. The students rarely used emotive feedback and elements of fun with each other, but they valued strongly what they did in their activities. Especially, in English lesson they employed a technique known as 'pair discussion'. During two 
lessons, the students sometimes showed care towards students and also encouraged each other. For example, one student asked her friend to read for her and consequently her friend showed kindness by helping her in reading. Some students also showed that they were gaining confidence in their own learning and willing to help their group mates. In addition, some students were observed as a mediator when intending to enhance students' motivation in the classroom by mediating their understanding of the correct answers during listening lesson. This form of mediation increased confidence of the students and enhanced their self-efficacy (Bandura, 1989).

Metacognitive mediation. Although this kind of mediation makes them aware about their thinking, our observations suggested that the students rarely used metacognitive mediation technique during activities of both lessons. The usage of this particular technique is evident in the following example. For instance, one student explained her answer to her friend. Also, she checked her friend's answer at the same time. In the aforementioned example, the students acted as a model that regulated her friend's learning. In the Japanese lesson, one student asked another student, "is it true?". The other student answered, "yes". Here, the student verified the answers. This type of mediation makes them self-regulated learners and they learn how to solve their problems by themselves by using promoting strategies and planned thinking.

Question 2: How the students perceive student centered learning approach in UUM?

In this section we present the results of interviews with four students enrolled in language courses in UUM. It explains the perceptions of undergraduate students about implementation of new approach in their activities. In this way, we divided the perceptions of students into six parts within student-centered learning namely environment, interaction, engagement, content, assessment, and instructional strategies.

Environment. The results from interviews with students regarding environmental mediation suggested that the environment is supportive for their learning process. However, there were some comments about the size of classrooms:

Mimi: Actually...I think this place is not too big, the distance between white board and chairs not comfortable. I just feel like $70 \%$ of comfortable.

Tina: I like learning in small classroom.

According to one of the students from Japanese class, environment was supportive to learning process:

Lee: We can interact and communicate better than just listen.

Lili from English class reported that environment was supportive to their learning:

Lili: we can learn by own self and teacher just guide us.

The students felt interested in their classrooms because they were using tools of technology:

Mimi: Our teacher adapt with us, communicate with us. We feel are her sisters and brothers, easy to communicate with teacher, she is very nice person.

In aspect of satisfaction about the environment inside classroom, the students had different comments:

Lee: its ok but I hope that be more entertainment, put something funny to easier learning. May be like music or pictures talk about culture of Japan.

Tina: I enjoy and little bit stress because lecturer always asks questions.

Mimi: About the learning process I'm very satisfied, because I can understand my teacher. I'm not satisfied just about the size of class.

The students were satisfied about the environment of their lessons. In some comments, the students presented their opinions to enhance or develop the environment in order to support student-centered learning. For example, Mimi commented that the classroom was not too spacious. This is the responsibility of administrators or faculties to establish a proper platform for collaboration in learning activities. Additionally, other students mentioned that they were satisfied about the learning process and they had varied views about the environment inside classrooms.

Interaction. It is evident from interviews that the curriculum provides opportunities for students to interact with each other in their learning activities in both of the two lessons:

Mimi: English course inside classroom provides to me a lot of opportunities to communicate with the other students. Because we learn in team and this makes us not shy and we have self-confidence in communication. 
The students from the two programs indicated that the instructor provided them appropriate environment and activities to interact with each other:

Lee: Activities not involve only one person; teacher always ask us to do activities in pair. So we can interact with other students.

Mimi: The role play, group presentation oral speech makes us interact with each other.

Thus, we could say that the students used cognitive mediation in their learning process inside classrooms. The students during interviews mentioned that they used some activities such as role play, pair discussion and group presentation which gave way to cooperative learning in their tasks. Within the group, the students provided the feedback to each other, challenged reasoning and conclusions, and most importantly, taught, helped, supported, applauded and encouraged one another in order to reach their goals. In this way, the students exchanged ideas and received information, therefore created understanding and developed knowledge.

Engagement. In this term, the students showed that the activities inside classroom help them to engage in learning process:

Mimi: Like role play makes me motivated and interested in my study.

Lili: The activities motivate me to do presentation and then when I do speech, also teacher teach us to be independent in anything need to do during our activities.

In addition, the students really liked when students learning activities become the main instructional strategies:

Tina: It's nice because I can interact with my friends, the activities improve the relationship between the students.

Lili: No stress during the activities, because we do the tasks and the lecturer just guides us

In this context, one student mentioned that the instructor rarely used emotive feedback during the activities:

Mimi: In this semester may be three or four time, she gives praise. She just says like that: ok good...rarely.

However, in Japanese class,

Lee: the teacher uses emotive feedback most of the time.

The students liked the learning activities which made them to get involved in learning process inside classroom. When students are engaged in their own learning, they will develop a better intrinsic belief in themselves. Student-centered learning activities allowed students the flexibility to reproduce their learning in a variety of ways which made them motivated to practice creativity during their tasks. In this way, the engagement and motivation of students lead them to a higher level of achievement. Additionally, the students' engagement and the immediate feedback obtained during lectures were noted in the observation process in both of the programs.

Content. The students showed high level of interest about the content of curriculum:

Mimi: This course is interest and I don't think that it challenges to me, because this course easy for me maybe $20 \%$ challenge from this course, just in presentation.

In addition, students shared varied viewpoints about improvement of content:

Mimi: I suggest that better change the place. The teacher needs to be more laughing because this makes me happier in classroom and she gives us emotive feedback.

Lili: Many exercises; push us to talk in English, for example role play, because we need to speak in them.

Moreover, the students indicated some suggestions about the content of their courses, two students from Japanese lesson reported:

Lee: I hope she can show more videos, music about Japan, not just study.

Tina: more interesting, more entertainment like the other classes teach students by sings.

The students seemed interested about the content which was provided from teachers. Consequently, they felt motivated and independent during classroom activities. Students presented several suggestions in order to improve the content in curriculum. More particularly, the students suggested the usage of technology to make the lessons more interesting. For instance, Tina commented, "more entertainment needs to be included in our class just like the other classes where they teach students by singing". This comment showed that students exchanged information 
about the content used inside the classrooms. Furthermore, the students knew that which strategy in the content is better for their learning process.

Assessment. The students' comments revealed that the assessment on part of the teachers was challenging to them:

Lee: yes, sometimes when I meet difficult question I need to find out, I must study hard.

Thus, the assessment strategies of the teachers made the students study hard and forced them to learn on their own. In other words, they forced the students to not only focus on the instructor, which consequently lead them to use the techniques related to student-centered learning approach.

Mimi from English class commented about the process to overcome barriers to learning in her classroom:

Mimi: I ask teacher. I ask myself... Why I learn English because this sometimes makes me motivated to study. I don't ask my classmates if I didn't understand because may English a little better than them. Some classmates ask me, then I ask teacher and explain to them after teacher explained to me.

In the comment, Mimi acted as a mediator between the teacher and her classmates, this process of mediation is one of the techniques of meditational tools that helped to implement student centered learning.

Lili: I have study more before enter the class, because she will ask questions, I must prepare before going to class, if I didn't understand I ask friend then the teacher.

Above-mentioned answers showed that the style of assessment was based on quiz, exercises and presentation. This style of assessment was preferred by both the instructors and the students because it provided a large number of testing items in a short time. The teachers used the formative assessment in their lessons which made the students learn through the whole period of study and challenged them to do large number of testing items in a short time. It was evident from the results that assessment is an important tool that can identify how students behave in learning process. When assessment was conducted to test high level of knowledge, learners had a high motivation to participate in effective learning practices such as teamwork. In contrast, when assessment was conducted to test low-level knowledge, learners often used an individual and surface learning approach to memorize lessons because this type of assessment did not require students to engage and negotiate about the meaning.

Instructional strategies. Several students reported that teachers made them self-regulated learner:

Lee: Teachers provide the activities make us thinking how to do something and learn by ourselves. What should we do? For example teacher gave us online quiz, so we must do it by ourselves and send to her online also.

Mimi: Speech makes me directly see her, get knowledge from her. Because teacher sometimes randomly choose students and talk front of classmate about title that she gave to us, this make me more confident.

In addition, the English teacher provided activities which made the students to participate actively:

Mimi: Roles play activities because it's fun and make the relationships more strong between us.

All students reported that the instructors helped students to become more active in their learning except Lili from English lesson:

Lili: Very boring. She just teaches us how to write.

Overall, students reported that their teachers provided them the activities which increased their confidence and made them more active in activities such as role play, speech and pair discussion. The students during the interviews showed the awareness about their teacher's strategies, cognition and developing competence while promoting strategic and planned thinking which is related to the metacognitive type of mediation.

\section{Discussion}

This study was conducted in order to enhance and develop independent learning in the foreign language context. Moreover, it intended to inquire, how to increase the level of usage of environmental, cognitive, affective and metacognitive mediation by the students during language courses at UUM. The current study's findings could be used in understanding the implementation of student-centered learning approach in higher education. Student-centered learning includes mediation tools such as collaborative learning, cooperative learning, problem-based learning, small group learning, and project-based learning. In this sense, we employed ECAM model of mediation (Abdul Rahim, 2007) as a framework to gain more understanding of students' mediational tools used in their classrooms. The students reported that the activities provided by instructors made them interact with each other. In addition, out of the four types of mediations in ECAM model, the students employed cognitive mediation most frequently. From the socio-cultural perspective, the learners were able to engage in the learning process through 
interaction and collaboration for the purpose of cognitive development. Supporting evidence to this idea was also provided by Mendoņ̧a and Popov (2014), who investigated a learner-centered class and a traditional teacher-centered class in an effort to clarify the mechanisms of scaffolding and the advantages of in-class interaction. They concluded that the second language learners had more opportunities for receiving scaffolding during the collaborative environment than the teacher-centered approach.

The conclusion complements Anton's (1999) study, who reported that interaction increases the opportunities of scaffolding as a facilitation mechanism to cognitive development. In addition, the findings of current study provided empirical support to what other socio-cultural researchers have maintained about the collaboration among peers (Mitchell \& Myles, 2004). Interaction between a pair of second language learners of the same cognitive level could provide the appropriate scaffolding that would lead to second language cognitive development (Swain \& Lapkin, 1998).

Our results of interviews also highlighted that the teachers provided the activities which made the students independent in their learning process and teachers merely guided them as facilitators. This finding is supported by Lee (2009), who indicated that successful implementation of a student-centered learning environment was highly related to how and when support and guidance should be provided for student learning. Teachers must be prepared to serve as facilitators towards students' learning if they expect to be successful in student-centered learning environments. For learning through mediation in university, students are expected to quickly develop communication skills, improve computer skills, their ability to use the internet, and acquire self-study skills (i.e., technology usage). The possession of aforementioned skills was clearly showed by the students in the two lessons observed in this study. Most of the students in this study indicated that they did not depend a lot on their teachers, because their teachers provided them with such tasks and activities that made them self-regulated learners.

\section{Implications}

Based on this research, many areas for future research have been identified. Firstly, understanding the perceptions of instructors and their experiences in student-centered approach is an important field to explore. A basic premise of student-centered learning approach is that learners should be the center of learning activities. Students are responsible for seeking information and understandings, while instructors, as facilitators, are responsible for guiding and motivating students to learn by providing them meditational tools and relevant resources. Brookfield (1988) argued that the role of facilitators as "resources for learning, rather than as didactic teachers who have all the answers". The shift from teacher-centered learning to student-centered learning approach requires instructors to change their roles during the activities in classroom. Instructors may not be prepared to change their roles in their classrooms. Teachers may also resist the new approaches to teaching process (Weimer, 2002). Therefore, it is important to explore perceptions of the instructors about student-centered learning and their experiences implementing these new settings in their teaching practice. Accordingly, future research could contribute to a better understanding of student-centered learning context by exploring the teachers' perceptions.

\section{Conclusion}

In conclusion, our findings indicate that cognitive mediation was the most frequently used mediation. Classroom observations as well as students' interviews indicated the usage of techniques that are vital for student-centered learning approach. However, the students' interviews showed that not all students enjoyed in classroom due to the size of classroom and lack of entertainment from teachers. These findings signify the crucial role of teachers in student-centered learning to motivate the students to involve in interactions and engagement in their learning process. Student-centered learning approach is extremely significant to all levels of education since it increases learners' motivation and engagement level. Future research should provide a rich data for the continuous improvement of student-centered learning approaches and their successful implementation in higher education.

\section{References}

Abdul Rahim, F., Hood, P. \& Coyle, D. (2009). 'Becoming experts': learning through mediation. Malaysian Journal of Learning \& Instruction, 6(1), 1-21.

Adamson, B., Kwan, T. \& Chan, K. K. (2000). Changing the curriculum: The impact of reform on primary schooling in Hong Kong (Vol. 1). Hong Kong: Hong Kong University Press.

Ahmed, A. K. (2013). Teacher-centered versus learner-centered teaching style. Journal of Global Business Management, 9(1), 22-34. 
Anton, M. (1999). The discourse of a learner-centered classroom: Sociocultural perspectives on teacher-learner interaction in the second-language classroom. The Modern Language Journal, 83(3), 303-318. https://doi.org/10.1111/0026-7902.00024

Asoodeh, M. H., Asoodeh, M. B. \& Zarepour, M. (2012). The impact of student-centered learning on academic achievement and social skills. Procedia-Social and Behavioral Sciences, 46(1), 560-564. https://doi.org/10.1016/j.sbspro.2012.05.160

Baeten, M., Kyndt, E., Struyven, K. \& Dochy, F. (2010). Using student-centred learning environments to stimulate deep approaches to learning: Factors encouraging or discouraging their effectiveness. Educational Research Review, 5(3), 243-260. https://doi.org/10.1016/j.edurev.2010.06.001

Bain, K. (2011). What the best college teachers do. Cambridge, MA. Harvard University Press. https://doi.org/10.2307/j.ctvjnrvvb

Bandura, A. (1989). Human agency in social cognitive theory. American Psychologist, 44(9), 1175-1184.https://doi.org/10.1037/0003-066X.44.9.1175

Benlahcene, A., Lashari, S. A. \& Lashari, T. A. (2017). Goal-orientation, epistemological beliefs towards intrinsic motivation among engineering students: A review. In IOP Conference Series: Materials Science and Engineering, 226(1), 012192. IOP Publishing. https://doi.org/10.1088/1757-899X/226/1/012192

Bonk, C. J. \& Cunningham, D. J. (1998). Searching for learner-centered, constructivist, and sociocultural components of collaborative educational learning tools. In C. J. Bonk \& K. S. King (Eds.), Electronic collaborators: Learner-centered technologies for literacy, apprenticeship, and discourse. New York, NY: Routledge.

Brookfield, S. D. (1988). Understanding and Facilitating Adult Learning. School Library Media Quarterly, 16(2), 99-105.

Brooks, J.G. \& Brooks, M.G. (1993). In search of understanding: The case for constructivist classrooms. Alexandria, VA: ASCD.

Brown, J. K. (2008). Student-centered instruction: Involving students in their own education. Music Educators Journal, 94(5), 30-35. https://doi.org/10.1177/00274321080940050108

Clarke, V. \& Braun, V. (2013). Successful qualitative research: A practical guide for beginners. London, United Kingdom: Sage.

Cooper, J. L., MacGregor, J., Smith, K. A. \& Robinson, P. (2000). Implementing small-group instruction: Insights from successful practitioners. New Directions for Teaching and Learning, 2000(81), 63-76. https://doi.org/10.1002/tl.8105

Corbin, J. \& Strauss, A. (2014). Basics of qualitative research: Techniques and procedures for developing grounded theory (3rd ed.). Thousand Oaks, CA: Sage.

Creswell, J. (2012). Educational research. Boston, Mass. Pearson

Denzin, N. 1970. The Research Act in Sociology. London: Butterworth.

Denzin, N. 1989. The Research Act: A Theoretical Introduction to Sociological Research Methods. (3rd ed.) Englewood Cliffs, NJ: Prentice Hall.

Eggen, P. D. \& Kauchak, D. P. (2001). Strategies for teachers: Teaching content and thinking skills. Boston: Allyn $\&$ Bacon.

Feuerstein, R. \& Feuerstein, S. (1991). Mediated learning experience: A theoretical review. In R. Feuerstein, P. S. Klein \& A. J. Tannenbaum (Eds.), Mediated Learning Experience (MLE): Theoretical, psychosocial and learning implications (pp. 3-51). London: Freund.

Handelsman, J., Ebert-May, D., Beichner, R., Bruns, P., Chang, A., DeHaan, R. \& Wood, W. B. (2004). Education: scientific teaching. Science, 304(5670), 521-522. https://doi.org/10.1126/science.1096022

Hannafin, M. J. \& Land, S. M. (1997). The foundations and assumptions of technology-enhanced student-centered learning environments. Instructional Science, 25(3), 167-202. https://doi.org/10.1023/A:1002997414652

Holt, L. C. \& Kysilka, M. (2006). Instructional patterns: Strategies for maximizing student learning. Thousand Oaks, CA: Sage. 
Humaid, A. S. M., Lashari. S. A., Saoula, O., Lashari, T. A., Benlahcene, A. \&, Lubana, A. (2019). Determining Students' Intention: The Role of Students' Attitude and Science Curriculum. Journal of Turkish Science Education, 16(3), 314-324.

Jones, A. M. (2007). Muslim and western influences on school curriculum in post-war Afghanistan. Asia Pacific Journal of Education, 27(1), 27-40. https://doi.org/10.1080/02188790601142900

Jones, R. \& Thomas, L. (2005). The 2003 UK Government Higher Education White Paper: A critical assessment of its implications for the access and widening participation agenda. Journal of Education Policy, 20(5), 615-630. https://doi.org/10.1080/02680930500222477

Kajornboon, A. B. (2005). Using interviews as research instruments. E-journal for Research Teachers, 2(1), 1-9.

Khan, B. H. (1997). Web based instruction. Englewood Cliffs, NJ: Educational Technology Publications.

Kornell, N. \& Bjork, R. A. (2007). The promise and perils of self-regulated study. Psychonomic Bulletin \& Review, 14(2), 219-224. https://doi.org/10.3758/BF03194055

Land, S. M. \& Hannafin, M. J. (2000). Student-centered learning environments. In D. Jonassen \& S. Land (Eds.), Theoretical foundations of learning environments, 1-23. Mahwah, NJ: Lawrence Erilbaum Associates, Inc.

Lee, S. J. (2009). Exploring students' beliefs about teaching and learning in relation to their perceptions of student-centered learning environments: A case study of the studio experience (Doctoral dissertation) University of Georgia, Athens, Georgia.

Liu, R., Qiao, X. \& Liu, Y. (2006). A paradigm shift of learner-centered teaching style: Reality or illusion. Arizona Working papers in SLAT, 13(1), 77-91.

Mendoņ̧a, M. \& Popov, O. (2014). Inner tensions in changing pedagogical approaches in Mozambican higher education. Comprehensive Journal of Educational Research, 2(5), 60-69. https://doi.org/10.1002/he.20114

Merriam, S. B. 2009. Qualitative Research: A Guide to Design and Implementation. San Francisco, SF: Jossey-Bass.

Mitchell, R. \& Myles, F. (2004). Second language learning theories (2nd ed.). London, United Kingdom: Arnold.

Nguyen, P.-M. 2008. Culture and cooperation: Cooperative learning in Asian Confucian heritage cultures. The case of Vietnam. Utrecht: Utrecht University, Institute of Education (IVLOS).

Pham, T. T. H. (2011). Issues to consider when implementing student-centred learning practices at Asian higher education institutions. Journal of Higher Education Policy and Management, 33(5), 519-528. https://doi.org/10.1080/1360080X.2011.605226

Pham, T. T. H. \& Renshaw, P. (2013). How to enable Asian teachers to empower students to adopt student-centred learning. Australian Journal of Teacher Education, 38(11), 65-85. http://dx.doi.org/10.14221/ajte.2013v38n11.4

Saulnier, B. M., Landry, J. P., Longenecker, H. E. \& Wagner, T. A. (2008). From teaching to learning: Learner-centered teaching and assessment in information systems education. Journal of Information Systems Education, 19(2), 169-174.

Shehzad, M. W., Alghorbany, A., Lashari, S. A. \& Lashari, T. A. (2019). Self-efficacy Sources and Reading Comprehension: The Mediating Role of Reading Self-efficacy Beliefs. 3L: Language, Linguistics, Literature, 25(3), 90-105. https://doi.org/10.17576/3L-2019-2503-07

Swain, M. \& Lapkin, S. (1998). Interaction and second language learning: Two adolescent French immersion students working together. The Modern Language Journal, 82(3), 320-337. https://doi.org/10.1111/j.1540-4781.1998.tb01209.x

Thanh, P. T. H. (2010). Implementing a student-centered learning approach at Vietnamese higher education institutions: Barriers under. Journal of Futures Studies, 15(1), 21-38.

Vygotsky, L. S. (1978). Mind in society: The development of higher psychological processes. Cambridge, MA: Harvard University Press.

Walsh, J. A. \& Vandiver, D. (2007). Fostering Student Centered Learning (SCL) Through the Use of Active Learning Exercises in Undergraduate Research Methods Courses: Employing the Research Project Model. Journal of Student Centered Learning. Retrieved, March, 9, 2019 from http://www.cfkeep.org/html/ snapshot.php?id=96156925890741. 
Wang, L. (2007). Sociocultural learning theories and information literacy teaching activities in higher education. Reference \& User Services Quarterly, 47(2), 149-158. https://doi.org/10.5860/rusq.47n2.149

Weimer, M. (2002). Learner-centered teaching: Five key changes to practice. San Francisco, SF: JosseyBass.

Wijnia, L., Loyens, S. M. \& Derous, E. (2011). Investigating effects of problem-based versus lecture-based learning environments on student motivation. Contemporary Educational Psychology, 36(2), 101-113. https://doi.org/10.1016/j.cedpsych.2010.11.003

Williams, M. \& Burden, R. L. (1997). Psychology for language teachers: A social constructivist approach. Cambridge, United Kingdom: Cambridge University Press.

Wohlfarth, D., Sheras, D., Bennett, J. L., Simon, B., Pimentel, J. H. \& Gabel, L. E. (2008). Student Perceptions of Learner-Centered Teaching. Insight: A Journal of Scholarly Teaching, 3(1), 67-74.

Wolk, R. (2010). Education: The case for making it personal. Educational Leadership, 67(7), 16-21.

\section{APPENDIX: INTERVIEW TOPICS AND QUESTIONS}

Questions About the environment

1) Do you agree that the environment is supportive for your learning?

2) Can you tell me what tools (technology) are using in the learning process inside the classroom?

3) Do you feel interested in this course? Why?

4) In which learning environment do you think you can learn better?

5) Are you satisfied in your classroom? Why?

Questions About the interaction

1) Do you think the curriculum can provide more opportunities for you to interact and other? Why?

2) Did you often asking the instructor questions and you respond to his/her questions?

3) Do you interact with other students when you face problems?

4) Do the activities in the classroom help students to interact with one another?

Questions About the engagement

1) Do you think activities in the classroom help you to be interested, motivated, focused and involved?

2) How can you describe your feeling when you are learning in the classroom where the lecturer is the main instructional strategies?

3) How can you describe your feeling when student learning activities become the main instructional Strategies?

4) How often lecturers provide emotive feedback?

5) How do you feel when you are working in group/alone? Why?

Questions About the content

1) What do you believe is effective learning for you in this course?

2) Do you think this curriculum content is interesting, challenging? Why?

3) Why do you think you need to learn a content of this course?

4) What concerns do you have about this course? Why?

5) If you can, how would you want your instructor to improve this course?

6) Is the content relevant with real world? Why? 
Questions About the assessment

1) How is the assessment done in this course?

2) Do the types of assessment help you to read a lot, think a lot?

3) Does the assessment challenging to you?

4) How do you feel when you are doing the assessment?

5) Do you think the assessment reflect the learning outcomes? Why?

6) What do you feel you need to do to overcome barriers to learning in your classroom?

Questions About the instructional strategies

1) Which one do you prefer the lecturer who lectures or lecturers who provide activities? Why?

2) Do you believe instructor enable students to become more active in their learning? Why?

3) How do different teaching approaches influence your learning?

4) Please briefly describe your preferred learning styles? Meaning, do you prefer to learn by doing? Listening, flashcard? Other style?

5) Do you think when you learn by doing will make you more confident to learn? Why?

6) When you are learning do you like to be told (lecturer) or do you like to solve problem by yourself?

7) Do you think activities provide by instructor make you self-regulated learner? Why? 